\title{
ANÁLISE DA QUALIDADE DA ÁGUA DOS RIOS VERDE E DO PEIXE NO DISTRITO INDUSTRIAL DO MUNICÍPIO DE TRÊS CORAÇÕES, MINAS GERAIS
}

\author{
Peterson Valério Guidi dos REIS ${ }^{1}$, Roberson Ricardo RANGEL ${ }^{1}$, Monike Faustino \\ LAUDINO ${ }^{1}$, Luiz Antônio Andriatta AYRES ${ }^{2}$, Maurício Cezar Resende Leite JÚNIOR ${ }^{3}$.
}

\author{
'Alunos do curso de Engenharia Ambiental/UNINCOR \\ e-mails: petersonguidi@yahoo.com.br, robersonr3@yahoo.com.br monikefaustinol@gmail.com \\ ${ }^{2}$ Orientador e Professor do Curso de Engenharia Ambiental/UNINCOR \\ e-mail: prof.luiz.ayres@unincor.edu.br \\ ${ }^{3}$ Co-Orientador e Professor do Curso de Engenharia Ambiental/UNINCOR - e-mail: \\ email:mauricio_cezar_leite@yahoo.com.br
}

Palavras-Chave: Análise, Rios, Distrito Industrial.

\section{RESUMO}

O presente trabalho vem demonstrar que os ecossistemas aquáticos estão sujeitos a diferentes formas de alterações. Essas alterações podem ser ocasionadas de forma natural ou principalmente antrópica. O aumento e as diversificações dos usos dos recursos hídricos, resultaram em uma multiplicidade de impactos, acarretando grandes pressões aos recursos hídricos, o que ocasiona situações de grande risco a saúde humana e conseqüentemente comprometimento de sua qualidade. O município de Três Corações - MG foi criado ás margens dos rios Verde e do Peixe, rios estes que sofreram e sofrem alteração em seu estado em decorrência de possíveis fontes poluentes industriais e domésticas. Através destes fatores o presente trabalho, busca a avaliação da qualidade da água destes rios em pontos estratégicos ao longo do Distrito Industrial do município através de alguns parâmetros que apresentam na sua essência o diagnóstico básico sob aspectos físicos, químicos e biológicos, consequentemente, da poluição decorrente da ação industrial no local. Espera-se conseguir avaliar satisfatoriamente a qualidade dos rios e comparar os resultados com as resoluções e padrões de potabilidade pertinentes citadas pela legislação vigente e principalmente pelo seu órgão legislador e executor sendo este representado pelo Conselho Nacional do Meio Ambiente - CONAMA. Os parâmetros a serem analisados permitirão concluir se os efluentes industriais despejados pelas indústrias nos cursos d'água passam por um tratamento correto e eficiente, com um efluente final de qualidade, apto a se reintegrar ao curso d'água. Após as diversas análises, espera-se também, que a qualidade da água em todos os pontos seja homogênea, principalmente as amostras coletadas a montante e a jusante do Distrito Industrial do município de Três Corações - MG, o que novamente irá comprovar se as indústrias comprometem ou não a qualidade dos recursos hídricos desses dois rios. 